\title{
REKONSTRUKSI MODEL PEMBELAJARAN CONCEPT SENTENCE DALAM PEMBELAJARAN MENULIS PUISI KELAS X MAN 1 MEDAN TAHUN PEMBELAJARAN 2019/2020
}

\author{
Alfi Yalda Ayumi ${ }^{1}$, Sukma Nabilah Daulay $^{2}$, Deby Luriawati Naryatmojo ${ }^{3}$, Haryadi $^{4}$ \\ Universitas Negeri Semarang \\ Program Studi Bahasa Indonesia Pascasarjana, Semarang \\ 19alfiyaldaa@gmail.com, ${ }^{2}$ sukmanabilahdly@gmail.com, ${ }^{3}$ debyluriawati@mail.unnes.ac.id, \\ $\underline{{ }^{4} \text { haryadihar67@mail.unnes.ac.id }}$
}

\begin{abstract}
Abstrak
Penelitian ini bertujuan untuk memodifikasi model pembelajaran concept sentence dalam pembelajaran menulis puisi. Metode yang digunakan peneliti adalah metode deskriptif kualitatif. Jenis penelitian ini tergolong dalam jenis penelitian kepustakaan dengan studi dokumen teks dan teknik pengumpulan data menggunakan teknik baca tulis berdasarkan penelitian sebelumnya.Berdasarkan hasil analisis data yang ditemukan oleh peneliti dapat disimpulkan bahwa model pembelajaran consept sentence dengan berbantuan media roll the can dalam pembelajaran menulis puisi dapat meningkatkan kemampuan peserta didik.
\end{abstract}

Kata Kunci: Rekonstruksi, Consept Sentence, Roll the can

\section{PENDAhuluan}

Trianto (2007:3) model pembelajaran merupakan kerangka konseptual yang melukiskan prosedur sistematik untuk mencapai tujuan belajar, yang berfungsi sebagai pedoman para guru dalam merancang dan melaksanakan pembelajaran. Sedangkan menurut Lefudin (2017:14) model pembelajaran adalah suatu perencanaan atau suatu pola yang digunakan sebagai pedoman dalam merencanakan pembelajaran di kelas atau pembelajaran tutorial. Suprijono (2012:46) merupakan pola yang digunakan untuk penyusunan kurikulum, mengatur materi, dan memberikan petunjuk bagi guru di kelas. Model pembelajaran berfungsi sebagai alat komunikasi yang penting bagi guru untuk memberi arah dalam pendesainan pembelajaran dalam rangka membantu peserta didik mencapai berbagai tujuan serta mencapai hasil yang baik. Berdasarkan beberapa pendapat diatas dapat disimpulkan model pembelajaran adalah penggambaran bentuk proses pembelajaran yang digunakan guru di dalam kelas dari awal sampai akhir secara efektif dan efisien untuk mencapai tujuan dalam proses pembelajaran. 
Model pembelajaran sudah mencerminkan penerapan suatu pendekatan , metode, teknik atau taktik pembelajaran sekaligus. Model pembelajaran terdiri dari syntax sintaksis), system social (sistem sosial), principal of reaction (prinsip reaksi), dan support system (sistem penunjang). Oleh karena model pembelajaran melibatkan banyak unsur, maka model pembelajaran merupakan bungkus atau bingkai dari penerapan suatu pendekatan, strategi, metode, teknik, dan taktik/gaya pembelajaran.

Dari uraian di atas, dapat disimpulkan bahwa model pembelajaran merupakan kerangka konseptual yang menggambarkan suatu prosedur sistematis. Model pembelajaran berfungsi sebagai pedoman dalam menyusun rencana pembelajaran. Model pembelajaran mencakup rancangan kegiatan belajar mengajar untuk mencapai tujuan pembelajaran. Berdasarkan pendefinisian dari ahli dapat disimpulkan bahwa model pembelajaran adalah Ruh dari pembelajaran itu sendiri yang menghidupkan proses demi proses belajar sehingga penting memahami jenis-jenis model pembelajaran untuk kemudian diterapkan pada praktiknya, ada banyak jenis dalam model pembelajaran yang bertujuan agar belajar berjalan baik sesuai dengan kemampuan peserta didik, keadaan dan lingkungan. Diantara jenis-jenis model pembelajaran yaitu pembelajaran kooperatif, pembelajaran kontekstual dan Concept Sentence.

Hasil wawancara dengan guru bahasa Indonesia kelas X MAN 1 Medan pembelajaran yang dilakukan di kelas $\mathrm{X}$ sudah menggunakan metode dan juga media seperti ceramah melalui power point. Kendala yang dihadapi siswa ketika sedang menulis puisi yaitu siswa sulit memunculkan dan mengembangkan ide, sulit mengekspresikan ide, pikiran, perasaan dan imajinasi yang akan mereka tuangkan dalam puisi. Siswa mengalami kesulitan untuk menyesuaikan tema dengan isi puisi. Siswa juga mengemukakan tentang kesulitannya dalam menggunakan diksi, citraan dan gaya bahasa. Mereka kesulitan untuk menemukan pilihan kata yang tepat,citraan dan gaya bahasa yang sesuai dengan objek yang dihadapi, sehingga mereka merasa kurang maksimal dalam menulis puisi. Berdasarkan hasil wawancara yang dilakukan dengan ibu $\mathrm{Hj}$. Dra. Murniati KS, beliau mengemukakan masih ada beberapa faktor yang menjadi kendala dalam penulisan puisi. Faktor yang disebabkan kesulitan siswa dalam pemilihan diksi dan motivasi dalam menulis puisi, pembelajaran menulis puisi 
hanya dilakukan dengan teori sesuai dengan buku paket. Guru menjelaskan materi tentang menulis puisi kemudian memberi tugas kepada siswa untuk langsung praktik menulis puisi.

Faktor yang disebabkan kesulitan siswa dalam pemilihan diksi dan motivasi dalam menulis puisi, pembelajaran menulis puisi hanya dilakukan dengan teori sesuai dengan buku paket. Guru menjelaskan materi tentang menulis puisi kemudian memberi tugas kepada siswa untuk langsung praktik menulis puisi. Masih ada beberapa faktor lain yang menjadi kendala dalam penulisan puisi. Salah satu faktor tersebut adalah siswa menganggap bahwa kegiatan menulis puisi adalah kegiatan yang sulit karena dalam menulis puisi mereka harus menguasai kebahasaan, mampu berfikir kreatif dan imajinatif. Dalam hal ini, media pembelajaran penting dan dibutuhkan. Guru dituntut kreatif dalam menghadirkan media alternatif baru untuk menstimulus siswa agar mudah menuangkan imajinasinya yang pada akhirnya mampu menulis puisi secara elastis. Proses pembelajaran di kelas, guru seharusnya melibatkan siswa pada suatu aktivitas yang penuh sekaligus mengembangkan potensi pikir mereka kearah yang positif. Tetapi pada kenyataannya, siswa kurang dilibatkan pada aktifitas yang dapat mengembangkan dan mengasah imajinasi mereka. Siswa hanya mendengarkan penjelasan guru, mencatat materi dan siswa di minta untuk menuliskan puisi tanpa bantuan media kecuali materi dari power point. Pengajaran seperti itu tentu membosankan dan sulit diterapkan yang akhirnya pengetahuan puisi sebagai karya seni yang harus dihayati telah dikaburkan. Hal ini diperkuat dan dikemukakan dalam penelitian Dalimunte (2006) yang berjudul 'Kemampuan Menulis Puisi dengan Memanfaatkan Wacana sebagai Sumber Inspirasi pada Siswa Kelas X SLTA Swasta Sutini Medan T.P. 2004/2005", yang menyatakan," Hasil kemampuan menulis puisi siswa yang terinspirasi dari wacana tergolong cukup dengan skor ratarata 61,67." Hal ini menunjukkan bahwa kemampuan siswa dalam menulis puisi belum tergolong baik. Dari kondisi tersebut peneliti berusaha mencari cara yang paling mudah dan menyenangkan untuk mulai menulis puisi. Salah satu cara yang menyenangkan dan mudah untuk diterapkan adalah dengan model consept sentence dengan media rool the can. Berdasarkan data diatas, dapat dirumuskan permasalah penelitian yaitu bagaimana rekonstruksi model pembelajaran concept sentence dalam pembelajaran menulis puisi. Tujuan dari penelitian ini adalah untuk mengetahui rekonstruksi model 
pemebelajaran concept sentence dalam pembelajaran menulis puisi.

\section{KAJIAN TEORI}

Winataputra (dalam Suyanto dan Djihad 2013:154) mengartikan model pembelajaran sebagai kerangka konseptual yang melukiskan prosedur yang sistematis dalam mengorganisasikan pengalaman belajar untuk mencapai tujuan belajar tertentu dan berfungsi sebagai pedoman bagi perancang pembelajaran dan para guru dalam merencanakan dan melaksanakan aktivitas belajar mengajar. Kemudian, Ahmadi dan Amri (2014:58) menjelaskan bahwa yang dimaksud dengan model pembelajaran adalah suatu rencana atau pola yang dapat digunakan sebagai pedoman dalam melaksanakan pembelajaran, merancang bahan, dan membimbing tindakan/aksi pengajar dalam setting pembelajaran di kelas atau setting lainnya.

\section{Concept Sentence}

Istarani (2012:192) model pembelajaran Concept Sentence merupakan penyampaian materi ajar melalui pemberian kata-kata kunci yang singkat dan padat akan tetapi mencakup seluruh materi yang diajarkan merupakan intisari. Suprijono (2012:46), pembelajaran dengan menggunakan model Concept Sentence dilakukan dengan mengorganisasikan siswa menjadi beberapa kelompok heterogen, kemudian guru menyajikan beberapa kata kunci sesuai dengan materi yang telah disampaikan sebelumnya. Kata kunci tersebut nantinya digunakan oleh siswa untuk menyusun kalimat dengan didiskusikan bersama anggota kelompok. Sedangkan menurut Huda (2013:96) model pembelajaran Concept Sentence merupakan model pembelajaran yang dilakukan dengan memberikan kartu-kartu yang berisi beberapa kata kunci kepada siswa, kemudian kata-kata kunci tersebut disusun menjadi beberapa kalimat dan dikembangkan menjadi paragraf.. Berdasarkan beberapa pendapat diatas dapat disimpulkan model pembelajaran Concept Sentence adalah suatu proses pembelajaran dimana siswa berperan dalam membuat kalimat dari pembelajaran yang menggunakan kata-kata kunci yang singkat telah disajikan oleh guru.

\section{Media Roll The Can}

Menurut Heinich (dalam Anitah dkk. 2009:6.3) media merupakan alat saluran komunikasi. Media berasal dari bahasa Latin dan merupakan bentuk jamak dari kata "medium" yang secara harfiah berarti "perantara", yaitu perantara sumber pesan dengan penerima pesan. Suyanto dan Djihad (2013:122) menjelaskan bahwa 
dalam memperlancar pencapaian tujuan dari pelaksanaan pendidikan di sekolah maka diperlukan sebuah media perantara, yaitu tidak lain adalah media pembelajaran. Salah satu media yang dapat digunakan dalam proses belajar mengajar adalah media permainan. Dalam Kamus Besar Bahasa Indonesia (KBBI), permainan merupakan sesuatu yang digunakan untuk bermain atau sesuatu yang dipermainkan. Tim Guru Sekolah Global Mandiri (2013:27-32) mengembangkan media-media pembelajaran yang salah satunya, yaitu Roll The Can. Media Roll The Can merupakan bentuk permainan yang bertujuan untuk memotivasi dan mengembangkan kemampuan sosial dan motorik siswa dalam berbahasa. Media Roll The Can mengembangkan kemampuan berbahasa siswa melalui tempelan tempelan kata di sebuah kaleng yang selanjutnya dikembangkan menjadi sebuah kalimat. Manfaat dari media Roll The Can ini, yaitu dapat memotivasi siswa untuk berlatih membuat kalimat-kalimat dengan menyusun kata-kata yang ditempelkan pada permukaan kaleng, dan mempermudah guru dalam menyajikan materi, serta meningkatkan daya tarik siswa terhadap mata pelajaran bahasa. Alat dan bahan untuk membuat media Roll The Can ini sangat mudah didapat, yaitu gunting/cutter, kaleng bekas berbentuk tabung, spidol aneka warna, kertas bekas, lakban/isolasi, dan lem. Cara membuatnya, yakni dengan mengunting kertas bekas yang disesuaikan dengan ukuran kaleng, menuliskan beberapa kata di atas potongan-potongan kertas bekas yang sudah digunting dengan spidol aneka warna, dan menempel setiap potongan kertas berisi kata-kata di atas permukaan kaleng dengan diberi jarak yang teratur antara satu potongan dengan potongan lain.

\section{Menulis}

Menulis merupakan suatu sarana berkomunikasi atau penyampaian pesan kepada orang lain secara tertulis yang diwujudkan dalam bentuk rangkaian lambang atau simbol grafis yang dapat dimengerti oleh penulis dan dipahami oleh orang lain yang membacanya. Menurut Saddhono \& Slamet (2014:151). H.G. Tarigan dalam dalam Saddhono \& Slamet (2014:154), mengungkapkan bahwa menulis pada hakikatnya ialah melukiskan lambang-lambang grafis yang menggambarkan suatu bahasa yang dipahami seseorang untuk dibaca orang lain yang dapat memahami bahasa dan lambang-lambang grafis tersebut. Dengan mencermati teori-teori di atas, dapat dikemukakan bahwa menulis adalah kegiatan mengungkapkan gagasan, ide, 
atau pendapat yang akan disampaiakn kepada orang lain (pembaca) melalui media bahasa tulis untuk dipahami tepat seperti apa yang dimaksud oleh penulis.

\section{Puisi}

Secara etimologi istilah puisi berasal dari bahasa Yunani "poeima" atau "Poesis" yang berarti pembuatan. Sedangkan dalam Bahasa Inggris disebut "Poem" atau "Poetry" yang berarti membuat atau pembuatan, karena lewat puisi pada dasarnya seseorang telah menciptakan suatu dunia tersendiri yang mungkin berisi pesan atau gambaran suasana tertentu, baik fisik maupun batiniah. Menurut Herman J. Waluyo menyatakan bahwa puisi ialah sebuah bentuk karya sastra yang mengungkapkan suatu pikiran dan perasaan penyair secara imajinatif dan disusun dengan mengonsentrasikan semua kekuatan bahasa dengan pengonsentrasian sebuah struktur fisik dan struktur batinnya.

\section{METODE PENELITIAN}

Berdasarkan tujuan yang ingin dicapai dalam penelitian ini maka metode penelitian yang akan digunakan adalah metode penelitian deskriptif kualitatif. Berdasarkan Modul Rancangan Penelitian (2019) yang diterbitkan Ristekdikti, penelitian kualitatif bisa dipahami sebagai prosedur riset yang memanfaatkan data deskriptif, berupa kata-kata tertulis atau lisan dari orang-orang dan pelaku yang dapat diamati. Maka, proses penelitian kualitatif dimulai dengan menyusun asumsi dasar dan aturan berpikir yang akan digunakan dalam penelitian. Data yang dikumpulkan dalam riset kemudian ditafsirkan. Populasi adalah keseluruhan atau sebagian objek yang diteliti. Dengan demikian, maka populasi dalam penelitian ini adalah seluruh siswa kelas X MAN 1 Medan tahun pembelajaran 2019/2020 yang berjumlah 351 siswa. Kelas X MIA (Matematika dan Ilmu Alam) 11 kelas. Dari populasi tersebut peneliti menemukan bahwasanya sampel pada penelitian ini yaitu kelas X MIA MAN 1 Medan.

\section{PEMBAHASAN}

Kajian mengenai model concept sentence berdasarkan data yang ditemukan berdasarkan teori dan beberapa jurnal penelitian sebelumnya, bahwasanya adanya kelebihan dan kekurangan pada model concept sentence.

\section{Kelebihan model pembelajaran consept sentence}

Model concept sentence sangat cocok untuk pembelajaran bahasa dan pembelajaran sosial. Pengajaran model ini dipandang efektif atau mempunyai kelebihan (Huda, 2013:317), meliputi:

1) meningkatkan semangat belajar siswa; 
2) membantu terciptanya suasana belajar yang kondusif;

3) memunculkan kegembiraan dalam belajar;

4) mendorong dan mengembangkan proses berpikir kreatif;

5) mendorong peserta didik untuk memandang sesuatu dalam pandangan yang berbeda;

6) memunculkan kesadaran untuk berubah menjadi lebih baik;

7) memperkuat kesadaran diri;

8) lebih memahami kata kunci dari materi pokok pelajaran;

9) siswa yang lebih pandai mengajari peserta didik yang kurang pandai.

Dari kelebihan-kelebihan diatas dapat dijelaskan:

1. Pertama, Meningkatkan semangat belajar siswa. Dengan metode pembelajaran ini diharapkan semangat belajar siswa meningkat. Dengan metode baru siswa menjadi lebih bersemangat, karena kebanyakan siswa menyukai dan tertarik dengan hal-hal baru.

2. Kedua, Membantu terciptanya suasana belajar yang kodusif. Dengan metode pembelajaran concept sentence kondisi kelas menjadi terkendali dan suasana belajar pun menjadi kondusif. Dengan suasana belajar yang kondusif penyerapan materi pembelajaran menjadi baik. Hal ini tentu saja meningkatkan hasil pembelajaran siswa.

3. Ketiga, Memunculkan kegembiraan dalam belajar. Metode pembelajaran concept sentence menimbulkan suasana yang gembira dan menyenangkan dalam belajar. Pada metode ini pembelajaran dikemas seperti sebuah permainan kuis sehingga siswa menjadi lebih senang dan bergembira.

4. Keempat, Mendorong dan mengembangkan proses berpikir kreatif. Metode pembelajaran concept sentence ini dapat mendorong dan mengembangkan proses berpikir kritis dan kreatif. Siswa dituntut untuk berpikir bagaimana menciptakan halhal baru yang menarik dan hebat. Dengan begitu, siswa menjadi termotivasi untuk berlomba-lomba menjadi yang terbaik. Hal itu tentu saja berdampak positif pada hasil pembelajaran. Dengan motivasi tersebut siswa menjadi meningkat hasil pembelajarannya karena mereka cenderung aktif.

5. Kelima, Mendorong siswa untuk memandang sesuatu dalam pandangan yang berbeda. Metode pembelajaran concept sentence ini juga dapat mendorong siswa untuk memandang 
sesuatu dalam pandangan yang berbeda. Siswa menjadi bertambah wawasan dan pengetahuannya. Mereka akan terbiasa menyikapi segala sesuatu dari sudut pandang yang berbeda sehingga mereka tidak lagi kaku dalam menyikapi suatu permasalahan.

6. Keenam, memunculkan kesadaran untuk berubah menjadi lebih baik. Dengan metode pembelajaran concept sentence, juga dapat memunculkan kesadaran siswa untuk berubah menjadi lebih baik. Dengan pengalaman yang bermacam-macam siswa akan menjadi lebih baik.

7. Ketujuh, memperkuat kesadaran diri. Metode pembelajaran concept sentence ini juga dapat memperkuat kesadaran diri siswa. Mereka dengan sendirinya akan sadar dan dapat menentukan hal terbaik yang harus dilakukannya.

8. Delapan, lebih memahami kata kunci dari materi pokok pelajaran. Dengan metode pembelajaran concept sentence siswa menjadi lebih mudah dalam menerima dan memahami materi pembelajaran yang disampaikan oleh guru. Hal ini karena semua siswa benar-benar terlibat langsung dalam proses pembelajaran. Tidak ada siswa yang pasif sehingga siswa benar-benar memahami materi pembelajaran.

9. Sembilan, siswa yang lebih pandai mengajari siswa yang kurang pandai.
Dengan metode pembelajaran ini, siswa yang pandai dapat membantu mengajari siswa yang kurang pandai. Sifat egoisme dan individual sudah ditanggalkan berganti dengan sikap saling membantu dan kekeluargaan.

\section{Kekurangan model pembelajaran consept sentence}

Kelemahan dari model ini menurut (Huda, 2013: 317) adalah;

1. hanya untuk mata pelajaran tertentu;

2. untuk yang pasif mengambil jawaban dari temannya.

3. Selama kegiatan diskusi kelompok berlangsung ada kecenderungan topik permasalahan yang dibahas meluas sehingga banyak yang tidak sesuai dengan waktu yang telah ditentukan.

4. Saat diskusi kelas terkadang didominasi seseorang hal ini mengakibatkan siswa yang lain menjadi pasif.

Tidak semua mata pelajaran dapat menerapkan model ini, akan tetapi model ini sangat sesuai diterapkan dalam pembelajaran bahasa Indonesia karena akan menambah pengetahuan dan kosakata baru bagi siswa. Seperti halnya model pembelajaran yang lain, model concept 
sentence pun mempunyai beberapa kelebihan dan kelemahan sehingga perlu adanya pemahaman dalam melaksanakan model tersebut.

\section{Rekontruksi model pembelajaran}

\section{Concept Sentence}

Model pembelajaran concept sentence sudah cukup baik jika digunakan dalam pembelajaran bahasa Indonesia, akan tetapi tidak semua mata pelajaran bisa menggunakan model pembelajaran concept sentence. Menurut peneliti model pembelajaran concept sentence ini sudah cukup baik jika diterapkan dalam mata pelajaran bahasa Indonesia khusunya dalam materi pelajaran bahasa Indonesia materi menulis teks puisi. Tetapi, alangkah lebih baiknya jika model pembelajaran concept sentence ini dikombinasikan dengan media pembelajaran yang sejalan maka model pembelajaran concept sentence ini akan jauh lebih baik jika diterapkan dengan penggunaan media roll the can kepada siswa. Media Roll The Can merupakan bentuk permainan yang bertujuan untuk memotivasi dan mengembangkan kemampuan sosial dan motorik siswa dalam berbahasa. Media Roll The Can mengembangkan kemampuan berbahasa siswa melalui tempelan- tempelan kata di sebuah kaleng yang selanjutnya dikembangkan menjadi sebuah kalimat. Manfaat dari media Roll
The Can ini, yaitu dapat memotivasi siswa untuk berlatih membuat kalimat-kalimat dengan menyusun kata-kata yang ditempelkan pada permukaan kaleng, dan mempermudah guru dalam menyajikan materi, serta meningkatkan daya tarik siswa terhadap mata pelajaran bahasa. Penggunaan model concept sentence dan media roll the can dapat meningkatkan kemampuan menulis puisi siswa dikarenakan dengan mengkolaborasikan modl dan media tersebut dapat menambah kosa kata bagi peserta didik serta memperluas kosa kata mengenai diksi/gaya bahasa dalam menulis puisi menjadi lebih baik. Penelitian mendukung media roll the can pada model concept sentence ini yaitu penelitian yang dilakukan oleh Alfi Yalda Ayumi(2020) menyatakan bahwa penggunaan media roll the can untuk meningkatkan keterampilan menulis puisi siswa MAN 1 Medan dapat dikatakan berhasil.

\section{SIMPULAN}

Berdasarkan hasil analisis data yang ditemukan oleh peneliti dapat disimpulkan bahwa Model pembelajaran merupakan kerangka konseptual yang melukiskan prosedur sistematik untuk mencapai tujuan belajar, yang berfungsi sebagai pedoman para guru dalam merancang dan melaksanakan pembelajaran. Sementara model 
pembelajaran Concept Sentence merupakan salah satu model yang dikembangkan dari cooperative learning. Guru memberikan kata kunci kepada siswa, kemudian dari kata kunci tersebut disusun menjadi beberapa kalimat dan dikembangkan menjadi paragraf-paragraf. Dengan kata lain, artinya bahwa model pembelajaran menggunakan model Concept Sentence dan media roll the can ini mengacu siswa untuk bernalar sebab didalamnya peserta didik digiring untuk membuat paragraf dari kata kunci pada pembelajaran sebelumnya. Adapun kekurangan model pembelajaran Concept Sentence dan media roll the can hanya dapat diterapkaan pada mata pelaajaaran tertentu serta memudahkan peserta didik yang pasif meniru jawab dari peserta didik lainnya.

\section{SARAN}

Penelitian ini dapat dijadikan sebagai sumber informasi dan tambahan ilmu pengetahuan tentang penggunaan model pembelajaran concept sentence dan media roll the can dalam membantu proses pembelajaran pada materi menulis teks puisi serta dapat memberikan sumbangan ilmu pengetahuan bagi mahasiswa yang mengambil jurusan bahasa dan sastra indonesia.

\section{DAFTAR PUSTAKA}

Huda, Miftahul. 2013. Model-model

Pengajaran dan Pembelajaran.

Yogyakarta: Pustaka Pelajar

Istarani, 2012. 58 Model Pembelajaran Inovatif. Medan: Media Persada Lefudin, 2017. Belajar dan pembelajaran. Yogyakarta: CV BUDI UTAMA

Shoimin, Aris. 2014. 68 Model

Pembeajaran INOVATIF dalam

Kurikulum 2013. Yogyakarta:

AR-RUZZ MEDIA

Suyono, H. 2016. Belajar dan

Pembelajaran Teori Konsep

dasar. Bandung: PT Rosdakarya

Bandung.

Suprijono, Agus. 2012. Cooperative

Learning. Yogyakarta: Pustaka

Pelajar

Trianto. 2007. Model Pembelajaran

Terpadu. Jakarta: Prestasi

Pustaka

Waluyo, Herman J. 1991. Teori dan

Apresiasi Puisi. Jakarta:

Erlangga.

Waluyo, Herman J. 1995. Teori dan Apresiasi Puisi. Jakarta: Erlangga.

Widodo, Rahmat. 2009. Model

Pembelajaran Consept Sentence. Website:

http://wyw1d.wordpress.com/2009/11/14/ model-pembelajaran-conseptcentence/., diakses 17 Juni 2021 